\title{
Cultural semiotic in Dayak's Babalai ceremonial at Paramasan as an form of maintaining Dayak language
}

\author{
Fajarika Ramadania, and Johan Arifin \\ STKIP PGRI Banjarmasin \\ baikhati27@gmail.com,johnkaltara@.gmail.com
}

\begin{tabular}{ll}
\hline Informasi artikel & ABSTRAK \\
\hline Keywords: & This research is entitled "Cultural Semiotic in Dayak's Babalai \\
tribe; Babalai; Language & ceremonial at Paramasan as a form of maintaining traditional \\
language". This research has long-term goal of introducing Dayak \\
Language in general and Dayak language culture, in particular, to \\
attract tourists to visit Paramasan, Banjar District of South \\
Kalimantan. This research identifies, analyzes, and interprets cultural \\
symbol which sourced from Dayak tribe mantra during Babalai \\
ceremony. The cultural symbols to be identified are the symbols based \\
on Pierce's trilogy of indexes, icons, and symbols. This study aims to \\
describe the Dayak tribe mantra used in Babalai ceremonial and to \\
analyze symbols in the Meratus Dayak's tribe mantra used during \\
Babalai event in Paramasan, Banjar district of South Kalimantan. \\
Each symbol and icon used in each culture contains its own cultural \\
values that are considered significant in its community. The study of \\
Dayak's Meratus mantra text would enrich the treasury of language \\
and culture in local-global communities and could strengthen \\
solidarity among nations and countries. The language used as a \\
medium in expressing or expression is a media to know historical \\
evidence as the context of an understanding of the identity of a culture. \\
Cultural identity emerges within a community not only as a color of \\
locality but also as a cultural expression that offers an alternative \\
image in society.
\end{tabular}

\section{INTRODUCTION}

Global developments result in the melting of geographical boundaries between regions and caused the flow of human movement from one region to another to be easier. This condition causes the presence of multicultural in a State. Multiculturalism is an ideology that emphasizes the importance of recognition and tolerance of diversity.

Parekh (in Piliang, 2007: 2) argues that multiculturalism must be understood not as a doctrine but as a perspective or a way of life. In multiculturalism, there is a principle that states that every culture is internally plural with the flow of thought changing and still presenting its identity. A cultural phenomenon from a semiotic perspective is a system of signs relating to each other that are conventional to obtain the meaning contained in it. Semiotics is a science that examines the signs in human life, which the signs should be taken into consideration (Hoed: 2007: 3). While cultural semiotics is a study of semiotics that specifically examines the system of signs that apply in a particular society culture. 
Dayak Meratus is a group of Dayak people settling in the village of Paramasan, Banjar district of South Kalimantan. The Dayak tribe holds a thanksgiving ceremony which is Babalai. This ceremony is held between JulyAugust which is believed to keep them away from crop failure. Through this ritual, they are begging to the God to help them in the next planting season to keep away pests and to obtain abundant crops.

Babalai ritual begins with a musical drum, and then Sang Damang begins to recite the mantra followed by other custom processions. The rhythm is mystically harmony. In Paramasan, $90 \%$ of the people are a descendant of pure Dayak Meratus. In this case, a number of population and surrounding environment greatly affect the perseverance of Dayak language by Dayak speakers in Paramasan, Banjar district. Jendra (2010: 144 -146) also says that the factors that preserve the language are the number of speakers, residence, identity, and cultural pride, and good economic conditions. Although Dayak tribes only minority communities in Banjar district does not mean they do not maintain their local language.

Language preservation depends on which language they choose to use in communicating, and also depends on language attitudes possessed by the speakers of the language in maintaining their local language. Dayak language event in Banjar District is a sign of multilingual society. A multilingual community is a society that has the ability to speak more than two languages when communicating or interacting with other members of the community (Holmes, 2001: 19). Multi-language basis has potential to cause phenomena for individuals or groups of individuals, especially for minority language speaker. The cause of the phenomenon is they are not able to preserve and maintain their local language; as a result, their local language will shift and will be extinct. However, if they can overcome challenges or threats by choosing their regional language as their identity, their local language will survive. Based on that background, the researchers conducted a research entitled "Cultural Semiotics in Dayak Meratus's Babalai ceremony event in Paramasan, South Kalimantan as a form of language preservation".

\section{METHODOLOGY}

This research is used qualitative approach due to semiotic analysis, and then the type of research used is the type of qualitative and interpretative research at the same time. In this study, the author used several ways to collect the necessary data. Researchers use data list techniques that fit the topic of this research, documentation, and literature research.

This research uses filling system technique and using semiotic analysis method. The steps of charging techniques as follows: After the researchers collect sufficient data, then researchers perform data analysis. Further data generated by making certain categories. This stage is called the filling system. After that, categorized data is interpreted by combining 
two dimensions or different theories that researchers selected. What could then be done include: Identifying the available signs in the Babalai event, Configuring the existed signs in the Babalai event, Interpreting one by one sign using the triangle of meaning Pierce and explaining it in its entirety, Describing the message of environmental concerns that exist in the event The constructed chapters use the signs in the spell of the Babalai event.

\section{DISCUSSION}

\section{History of Semiotics}

The development of semiotics (the science of signs) has begun from the days of Konu, medieval times, renaissance (reborn), and entered modern times. Semiotic science begins with linguistic science with its character Ferdinand de Saussure (1857-1913). Saussure is not only known as the Father of Linguistics but also widely referred as a semiotic figure in his Course in General Linguistics (1916). In addition, there are important figures in semiotics namely Charles Sanders Peirce (1839-1914) an American philosopher and Charles William Morris (1901-1979) who developed behaviorism semiotics. Semiotic figures who developed modern semiotic theories were Roland Barthes (1915-1980), Algirdas Greimas (1917-1992), Yuri Lotman (1922-1993), Christian Metz (1993), Umberco Eco (1932), and Julia Kristeva (1941). Linguists other than Saussure who worked with semiotics framework were Louis $\mathrm{Hj}$ lem slev (1899-1966) and Roman Jakobson (18961982). Semiotics is a science or method of analysis to examine signs. Signs are the tools we use to try to find a way in this world, in the midst of humans and with humans. Basically, these semiotics learn about how humanity and how to mean things.

The beginning of this approach was developed by Ferdinand de Saussure in the early 20th century. Saussure was a French linguist who laid a foundation for structuralize approach to language and culture. In semiotics, the symbol is understood as a symbol determined by its dynamic object, which means that it must be thoroughly interpreted. In this case, interpretation in an effort to examine the meaning of symbol reflects elements of the learning process and the growth or development of experiences and agreements in society. To date, there are at least nine kinds of semiotics that existed; these semiotic types are semiotic analytic, descriptive, faunal zoo semiotic, cultural, narrative, natural, normative, social, and structural. Based on the various semiotics above, this research goes to semiotic cultural research, specifically to examine the sign system in the social culture. (Rokhmansyah, 2014: 103) "Semiotics according to Berger has two figures, namely Ferdinand De Saussure and Charles Sanders Pierce. Both figures develop semiotics science separately and do not know each other "(Tinarbuko, 2008: 11). Saussure in Europe and Peirce in the United States, Saussure's scientific background is linguistic, while Peirce philosophy. Saussure called the science he developed semiology.

Charles Sanders pierce proposed semiotics as an approach placed within the tradition of 
Charles Sanders Pierce's thought in order not to fall into a conceptual ambiguity. The classification efforts done by Leh Peirce toward the signs seemed simple but very complicated. However, the distinction of the simplest and most basic types is icons, indices, and symbols. While in the theory of Ferdinand de Saussure along the development of Charles Sanders Peirce's thought until much influenced to Ferdinand de Saussure. According to his conceptual traces in the Saussuren linguistic tradition was known for his distinctive dichotomous concept of dichotomy as a scientific discipline. Peirce proposed a theory of meaning triangle consisting of three main elements, namely signs, objects, and interpretations. Signs are something that is physically shaped that can be captured by the five human senses and is something that refers to something other than the mark itself. The sign by piece consists of symbols (marks arising out of agreement), icons (marks emerging from physical representation), and indexes (signs arising from causal relationships). Interpretation or user sign is the concept of thinking of the person who uses the sign and lowers it to a certain meaning or meaning that is in someone's mind about the object referenced by a sign. While semiotic proposed by Ferdinand De Saussure is divided into two parts (dichotomy) that is signifier (signifier) and signified (signified). According to Saussure the sign consists of sounds and images called signifier or marker. The concepts of sounds and images are called signified.

\section{Various Kinds Of Semiotics}

1. Semiotic analytics

Semiotic analytics is a semiotic that analyzes the sign system. Pierce says that semiotics mocks signs and analyzes them into ideas, objects, and meanings. Ideas can be said to be symbols, whereas meaning is a burden contained in a symbol that refers to a particular object.

2. Semiotic descriptive

Semiotic descriptive is semiotic that notices the sign system that can be experienced now even though there is a mark that has always been fixed.

\section{Semiotic Faunal}

Semiotic faunal is a special semiotic attention to the sign system produced by animals.

\section{Cultural Semiotics}

Semiotic culture is a semiotic that specifically examines the sign system that exists in the culture of society.

\section{Semiotic narrative}

Semiotic narratives are semiotic that discusses the sign system in narratives that are tangible to myths and oral stories.

6. Natural Semiotics

Semiotic natural is a semiotic that specifically examines the sign system generated by nature.

\section{Semiotics normative}

Semiotic normative is a semiotic that specifically discusses the sign system created by the norms.

\section{Semiotic moral}


Semiotic moral is a semiotic that specifically discusses the sign system made by human beings embodies symbols, both symbols and words in the form of a sentence.

\section{Structural Semiotics}

Structural semiotics are semiotics that specifically examine sign systems manifested through language structures.

\section{Roland Barthes Semiology Model}

According to Roland Barthes, semiotics is a science or method of analysis to examine signs. Barthes distinguishes two meanings (signification) of the semiotics of denotation and connotation. Denotation is the descriptive and literal level or meaning agreed upon by all members of the culture, and the connotation of meaning is generated by the relationship between the signifier and the broad culture that includes the beliefs, attitudes, frameworks, and ideologies of a social formation. Semiology, in Barthes terms basically is to study how humanity (humanity) to use things (things), meaning (to signify) in this case cannot be mixed with communicating (to communicate). Meaning means that the object is about to communicate, but also constitute a structured system of signs.

\section{Denotation}

Denotation is what the sign represents of an object. In a general sense, denotation is usually understood as literal meaning, its "true" meaning (Wibowo 2011: 22). This signification process, traditionally referred to as denotation, usually refers to the use of language with the meaning that corresponds to what is spoken. But in Semiology Roland Barthes and his followers, denotation is the first level of signification system, while connotation is the second level.

\section{Connotation}

Connotation is a term used by Barthes to indicate the second stage of significance. This illustrates the interactions that occur when a sign meets the feelings or emotions of the reader and the values of his culture. Connotation has subjective or least intersubjective meanings. The connotation works in a subjective level so that its presence is not realized. Readers easily read the meaning of connotative into a denotative meaning. In the Barthes Framework, the connotation is identical to the operation of ideology which he calls the "myth" and serves to express and justify the prevailing dominant values in a given period.

\section{Myth}

In the mythical mythology of Barthesupa, there are cultural references (sourced from existing cultures) used to describe the symptom or reality designated by symbols, which is not the connotative meaning of the symbols that exist with art history (in addition to culture). In other words, the myth of work as a deformation of the symbol that then strings certain meanings with the basis of the historical and cultural values of society. For Barthes mythological not only in the form of words alone, inseparable, photography, film, scientific reports, sports, performances, even advertisements and paintings. In the hands of 
Barthes semiotic is widely used as a tool for critical thinking.

\section{Culture}

Culture is a comprehensive lifestyle. Culture is complex, abstract and broad. In Sanskrit the word culture comes from the word buddhayah which means reason. In Hindu philosophy, reason involves all elements of the five senses, both in the cognitive, sensory (affective), as well as behavioral (psychomotor). While other words that also have the same meaning with culture is 'culture' originating from the Romans, cultura, usually used to call human activities cultivate the soil or farming. Culture is the result of human creation, feeling and initiation in the form of physical and non-physical works.

\section{Cultural Semiotics}

For structuralists, the task of scientists is to uncover the conceptual structure based on the structure that various cultures organize their perceptions and understanding of the world. The attempt of structuralism is to find the way people understand the world, not what the world is like. Semiotics as one of the mass media studies has become an important approach in media theory since the late 1960s, as a result of Roland Barthes's development. According to Roland Barthes, semiotics is a science or method of analysis to examine signs. Signs are a set used in the framework of attempting to reach the path of this world, in the midst of humanity and with humanity.

He also distinguishes two meanings (signification) of semiotics that is denotation and connotation. Denotation is the descriptive level and literal meaning that all members of the culture agree upon. At the level of connotation, the meaning is generated by the relationship between the signifier and the broad culture that includes beliefs, attitudes, frameworks, and ideologies of a social formation. Semiology, or in Barthes's terms, semiology, essentially wants to study how humanity (humanity) use things, interpret (to signify) in this case cannot be mixed by communicating (to communicate). Meaning means that the objects are about to communicate, but also constitute a structured system of signs. (Sobur, 2003: 15). Preminger, et al. In Pradopo (1995: 119), says semiotics is the science of signs. It considers that the social/cultural phenomenon and culture are signs. It studies the systems, the rules, and the conventions that allow them to have meaning. In the field of literary criticism, semiotic research involves literary analysis as a language use that relies on (prescribed) additional conventions and examines the traits (properties) that cause various modes of discourse to have meaning.

Analysis of different cultural identities is a channel to inheritance a nationality in which one of the national heritages is language. The language used as a medium of expression or expression tool to find historical evidence as the context of an understanding of the identity of a culture. Cultural identity emerging in a community is not only a localized color but also as a cultural expression that offers an alternative image in society. 
Literary works use language as a medium of delivery. Language is a communication tool capable of mediating the conveying of ideas from the author through a sign. Starting from the language as a system of signs, the literary work of language is the semiotic system or the system of signs. Hoed (2014: 05) explains that semiotics is the study of signs in human life. That is, all that is present in human life is seen as a sign that is something to be given meaning. The cultural phenomenon from a semiotic perspective is a system of signals relating to each other that are conventional to obtain the meaning contained in it. Semiotics is the study of signs in human life, in which the signs must be, interpreted (Hoed, 2007: 3). While cultural semiotics is a semiotic study that specifically examines the system of signs that apply in a particular society culture. The concept of the sign used as a reference in this paper is the Peirce sign trilogy of icons, indices, and symbols. Icons are a sign that can describe the main features of something, which resembles what it represents (the concept of an equation). An index is a sign that is present associatively due to the presence of a fixed reference characteristic (causal relationship). The symbol is something that is used to designate something else by agreement (convention).

Literary work is a sign system that has a meaning that uses language as its medium. Language as a medium of literary work is a system of semiotics, which is a system of meaningless semiotics. Language is a system of semiotics based on or determined by the convention (agreement) in society. Literature is a system that has its own conventions. In literature there are literary types (genres), namely the type of prose and poetry literature. Prose has a variety: short stories, novels, and romance and poetry have variations: lyric poems, poems, classic Malay poem (pantuns), sonnets, ballads, and so on. Poetry (rhyme) in semiotics is a structured and meaningful sign structures determined by the convention. Understanding the poem is none other than understanding the meaning in the poem.

Analyzing the poem is an attempt to grasp the meaning of the poem. So, the semiotic approach is the attempt to analyze the literary works. The rhyme in particular is a system of signs and determining what conventions allow literary works to have meaning. Literary research with semiotic approach is actually a continuation of structuralism approach. Structuralism cannot be separated with semiotics, because literature is a meaningful structure of signs. Without paying attention to sign system, its sign and its meaning, and sign convention, the structure of literary works cannot be understood optimally.

Endraswara (2008: 64) says that semiotics research is the study of signs. Literary works will discuss about signs. Of course, signs have been established by the authors that there are no specific systems, conventions, and rules that need to be understood by researchers. Regardless of the signs, the full meaning of literary works is made. The meaning of literary works will not be very optimal if not discarded with a sign of discourse. Semiotics is the study of signs. Eco (2009: 22) explains "signs are defined as 
anything that conforms to existing social conventions, can be used as something that reflects something else". Semiotics becomes a term for an approach.

A semiotic approach is an approach that departs from the view that everything contained in a literary work is symbols or codes that have a certain meaning or meaning. Meaning or meaning it relates to the system adopted. So it can be concluded that semiotic is the study of the signs, the functioning of sign and the production of meaning. Signs are something for someone to mean something else. Semiotics as a model of social science understands the world as a relationship system that has a basic unit called a 'sign'. Thus semiotics is the study of the signs and is often interpreted as the science of signification.

This discipline not only deals with language cues, but also relates to non-linguistic cues in human communication. To understand verbal and nonverbal language then it takes science of signs. The term semiotics is often used in conjunction with the term semiology because it is a branch of research or a scientific approach that studies the relationship between signs. Semiotic own goal is to know the meaning contained in a sign so it is known how communicators convey the message. Speaking the concept of a sign, it will not be released with the concept of meaning.

A sign signifies something other than itself, whereas meaning is the relationship between an object or an idea in a sign. The meaning of the word is the field of study discussed in semantics. Different types of meaning of the word are examined therein. The meaning of denotative and connotative is the kind of meaning that exists in this study. The meaning of denotative is the true meaning, while connotative meaning is a meaning that is not the real meaning. In addition, semantics also examines the symbols or signs that express the meaning, the relationship between the meaning of one with another and its influence on humans and society.

Semantic understanding is related to semiotic sense because both include meaning in human communication. The study of the meaning in linguistics is called semantics, whereas the study of signs is semiotic, but they are closely related to each other because they cannot escape with meaning. The meaning studied is the meaning of the elements of language, whether in the form of morphemes, words, or sentences. A language element called a word that is often heard or read commonly called symbol (symbol). Symbols in semiotics are called signs (sign). Therefore, the symbol has a load called meaning and meaning is a semantic object, while the symbol is a semiotic object. Then it is very clear the relationship between semantics and semiotics. From point of view of Indonesia, the culture of the Sansakerta language "buddayah", the plural form of buddhi which means mind or reason. The word budaya is the development of the compound word budidaya, which means power and reason. Therefore they distinguish between culture and culture. Culture is a way of life of a society and develops in a community group passed down from generation to generation. 
While Anthropholinguistic culture (Sibarani, 2004: 5) its use as a whole group of people who are aware in the knowledge, actions, and results of his work as a social form used to understand the environment and be a book of his behavior to achieve peace.

This study uses a cultural semiotic approach as a discipline that specifically examines the prevailing sign system in society to dissect the uniqueness and meaning embodied in every culture. Sulistyowati and Tarsyad (2017: 24) "put forward his opinion as follows because semiotics study the relationship between markers and omens, then the science of language also includes semiotics". The relationship between the sign and its reference can be divided into three types.

\section{Icons}

There is a similarity between the reference and the sign. The sign is indeed similar to the reference or is a picture or direct meaning of the omen. For example, a photo is directly from the person being photographed. This icon can still be divided into two kinds, namely:

a. Typical icons, the resemblances seen here are relational resemblances. Thus, including signs and relationships between which no one is referenced, for example the wording in the sentence.

b. The metaphoric icon, this icon has no resemblance between the sign with its reference, which is similar to a sign between two peaks by the same word.

Sample Icons; All sorts of drawings, charts, diagrams, and photos.

\section{Index}

These terms are meaningful between the sign and its reference there is an existential closeness. The marker is the result of a sign (causality). In literary works, the depth of the grim atmosphere is usually an index that people are grieving. Danesi (2012: 37) "in a word, ordinary index used in and with precisely on the practices and reference. For example, an index at the end of a book is an alphabetical list that contains the name, place, and subject used for printing, and lists the pages or pages where the goods are free"

There are three basic colors, namely:

A. Information about special objects (space). Hand-made marks such as pointing fingers, explanatory words such as or, adverbs such as or, and figures like arrows, are all examples of space indices.

b. This index interconnects objects in terms of time. An explanation such as, or, lines representing time points originating from left and right, and dates on the calendar are all examples of temporal indices.

c. This index interconnects parties who take part in a video. A person's pronoun like, or an indefinite pronoun like, is an example of an index of people ".

\section{Symbols}

The marker is not a cause and a direct result of omens, but the relation between conventionally established sign and reference. Thus, there is already agreement between the user of the mark with its reference.

A. The basic concepts of semiotics 
There are four basic concepts of semiotic:

\section{Charles Sanders Peirce}

In order not to fall into the conceptual confusion, semiotics note in the writings of Charles Sanders Pierce. Armed with these detailed concepts, we can start from other semiotic theories.

a. semiotic and Triadic Structure

"A sign or representation has direct track relationships with interpretations and objects". The so-called semiotic process is a process that combines the entity called the representative with another entity called the object "(Budiman, 2011: 17). In the process of semiotic will produce an endless relationship, then in turn an interpretation will become a representation, be interpreted again, and so on. This endless movement by Umberto Eco and Jacques Derrida was then formulated as infinite semiotic. Examples of semiotic are potentially ongoing, e.g., a telephone on traffic signs is a representation then it may potentially be associated with other signs as its interpretation, for example, an object in Indonesian, telephone. The phone will in turn refer to the object in the form of for example a communication device in the form of a real phone.

b. Double Typology

The distinction of the simplest and most basic signs is the icon, index, and symbol based on the relation between representation and its object.

2. Le Groupe $u$ and I.A. Richards

According to this theory, there are two types of relationships commonly used to construct retired figures, namely: (1) a whole is divided into parts or (2) a class is divided into its members the most basic rhetorical figure.

\section{Roman Jakobson}

Roman Osipovich Jacobson born October 11, 1896 is a nobleman and literary theorist. As a structuralist, he was quite influential in the first half of the 20th century. His vast interest in fields other than linguistics led to influences in semantics, semiotics, poetry, music, visual arts and cinema. Reading his theories would inevitably intersect with big names like Saussure (structuralism in linguistics), Peirce (semiotic), Buhler, Levi-Strauss, Barthes, Hymn, Boaz, Whorf, and Bloomfield. Jakobson's theory is not solely concerned with poetic language or poetic language, but poetic function is also found in almost every kind of discourse. Hence, it could be called with aesthetic function.

\section{Towards Metaphor Ology}

Metaphor has become one of the most interesting topics of discussion throughout the history of semiotics and thus forms a specialized field of semiotics that can be called metaphorology.

\section{Meratus Dayak Culture}

One of the elements of culture is art, which has the struggle and power if it has a function or role in the life of the community. A form of performing arts will survive and thrive in the life of the supporting community as long as it is needed and has a socio-cultural function in people's lives (Haryono, 2008: 11). The implementation of Babalai ceremony always 
presents the performing arts one of which is a mantra or singing. This ritual is a means or completeness of a ceremony, so the dish of singing and mantra becomes a unity in ceremony Babalai. Hence, case with mantra and singing which is a unity that is interconnected in Babalai ceremony and has an important influence in the socio-cultural environment of the Meratus Dayak community. In this case, it seems clear that the relationship between the Babalai ceremony and the mantra happens to be interconnected and give each other the power of each other's functions. Mantra in Babalai comes in the form of ritual performing arts and is one of the local wealth that has a sacred function for its supporting community. Given that the function of performing arts can be classified into two, namely the primary function and the secondary function (RM Soedarsono, 2002: 126). Performing arts include as a means of ritual, personal entertainment, and aesthetic presentation. The secondary function indicates a passion in togetherness and as a medium of communication between and among Babalai ceremonial buffers.

Dayak Meratus usually held cerasi syukur adat which is Babalai. Tradition was held every mid-year after the rice harvest season arrived. For Meratus Dayak tribe, the implementation of this tradition has significance. So strong their belief in the meaning of this tradition, long before the tradition carried out all the needs traditions have been prepared. The gahanal tradition is usually held for 5 to 12 days. This determination is based on the number of crops gained during one year.

\section{Language Perseverance}

Trask (1997: 126) reveals language preservation is a use a language continuously by the speaker, especially in the state of the language being in the pressures of other languages. This happens because the community collectively decides to continue using the language (or languages) they have traditionally used. With the Bloomfield language concept (1933: 326), saying that language is a sign system for expressing, shaping and symbolizing cultural reality. Among all forms of symbols, language is the most complex, subtle, and evolving symbol. Now humans have agreed together, in their interdependence over the centuries, to make the sounds they create with the air blowing lungs, throat, tongue, teeth, and lips, systematically representing events in their nervous systems, language is called a system of agreement.

Referring to the above expression, Dayak language in its concrete form, which is a speech (release) in the narrative associated with social strata of society that can be used for social and can be used to realize various forms of ideas by Dayak people. Introduction in everyday language as a tribal society, or a society that directly has a tangible identity of Dayak language.

Starting from the above description, the Dayak language defense in this paper is conceptualized as an effort made by the 
community so that Dayak language is still used. Related to that, loyalty supporters is one important factor in the Dayak language defense. Loyalty is rooted in the source - a person. Implementation is seen in such behavior as not embarrassing to use Dayak language in the association; participating in official Dayak battles; participate in correcting Dayak mistakes used by others. Thus, language preservation is closely related to culture, society, and globalization. The defense of the language depends on the speakers themselves as the language users and the efforts made by the community itself. Holmes (2001: 60-64) says that efforts to maintain language use are positive attitudes, local language habits, language worship of the mother tongue (local language) and customs of visiting family. Furthermore, Jendra (2010: 159-160) says that efforts to maintain the use of regional languages can be done by governments, nongovernmental organizations (nongovernmental) such as radio broadcasters, influential publishers and Jains etc. and the latter can be done by individuals.

\section{RESULTS}

As has been done before, the results of research conducted doing cultural semiotics analysis in the event of Babalai tribe Dayak Paramasan as a form of language defense is as follows.
A sketch of lamin. A. Dinding, B. Pilar, C. Tangga

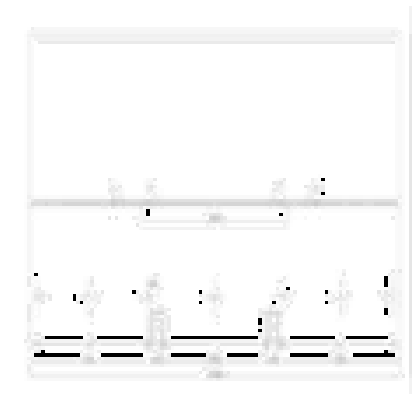

On this part of the wall narrates the Dayak genealogy in the form of carvings, where a king leads and guards every head of the Dayak sub-tribe which is depicted in the form of a human statue in the center. There is a jar located just below the feet of a human statue that gathers all the tribal chiefs and gongs on its top as a cover so as not to get scattered. While each head of this tribe is described in the form of a white sphere connected to the curved lines that connect and tied together. Crocodiles represent and bear a resemblance to an object. It can be deduced that Crocodile ornaments can be classified into an icon. Dayak Kenyah people assume that crocodiles are one of the reptiles that symbolize the underworld. The crocodile motif has a magical value and is believed to be the incarnation of the god or spirit of the ancestor, so it can be classified in the index. The existence of crocodile ornaments in Kenyah Dayak society becomes a symbol of the underworld, water, fertility, and supernatural powers. This crocodile ornament teaches both hunting and war skills in the past. The denotation is power, shrewdness and supernatural powers. Crocodile itself is one of many animals found in tropical rainforests that have many rivers 
such as Borneo. The connotation is to reflect strength, magic, supernatural, water, and fertility. Crocodiles are one of the most important animals in their culture. While the social aspect is used as a symbol of strength and supernatural powers, the reminder that even in difficult situations must remain strong as the increasing number of migrant tribes and their influences takes an attitude that they must also be able to maintain their traditions and traditions in the community Babalai event.

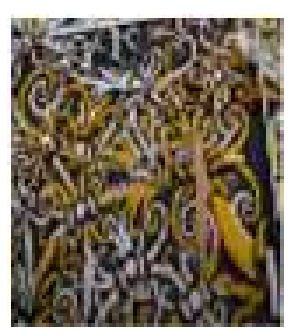

Curve and circle lines are the basic formations that are often found in the carving of the Dayak tribe. Curved or circular ornaments do not represent and have a resemblance to an object, so they cannot be classified as icons. The curved and circular lines take the base motif of the distilled plant in such a way that it does not resemble its original form. Curved lines and circles are representations of plant shape. The shape is similar to that of ferns whose leaves are young and curved in the shape of a spiral. Curved or circular ornaments can be categorized into indices. The embodied index is that the existence of curved lines and inner circle of ornaments is a representation of its environment. In the Dayak Kenyah community is a symbol of the unfailing descent of the Dayak community that can unite the Dayak community and symbolize every tribe and subtribe Dayak in Kalimantan. This curved and circular ornament teaches about brotherhood. Its denotation is the symbol of unity of all Dayak communities in Kalimantan that must be maintained. Curved lines are shaped like tendrils and ferns are grown in Kalimantan.

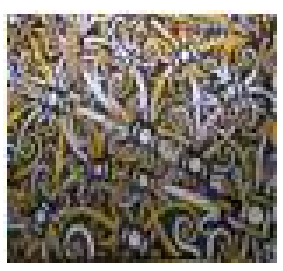

The depiction of the human figure is symbolized as the figure of the ancestor and the symbol of the supernatural forces of repellent. The human ornament represents and bears a resemblance to an object. So it can be classified into icons.

This human motive as a reminder of the ancestors and considered to keep them from misfortune or connotation is as a symbol of all the heads of Dayak tribes are intertwined, intertwined one with another with a line of interlocking. The social aspect is as a symbol of the descendants and every Dayak chiefs in Kalimantan. The shape of the arch and the inner circle of ornaments are used as a symbol of unity among Dayak people.

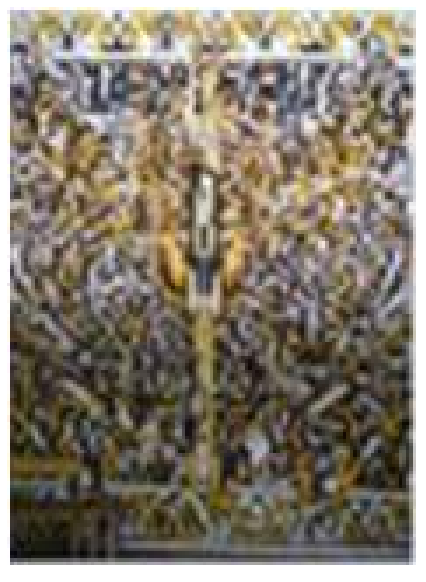




\section{CONCLUSIONS}

Based on the result of the research, it could be concluded that the signs existed in Babalai Dayak tribe ceremony in terms of language preservation could be preserved by the speaker. As a result, the possibility of shifting is relatively minor due to in Dayak tribe there are many more icons, indices and also symbols included in semiotic cultural.

\section{REFERENCES}

Amir, Yasraf Piliang. (2003). Hipersemiotika Tafsir Cultural Studies Atas Matinya Makna. Yogyakarta: Jalasutra

Bloomfield, Leonard. (1933). Language. New York: Holt, Rinehart, and Winston

Budiman, Kris. (2011). Semiotika Visual.

Yogyakarta: Jalasutra

Danesi, Marcel. (2012). Pesan,

Tanda dan Makna. Yogyakarta:

Jalasutra.

Eco, Umberto. (2009). Teori

Semiotika:

Signifikasi

Komunikasi, Teori Kode, Serta

Teori Produksi-Tanda..

Yogyakarta: Kreasi Wacana

Endraswara, Suwardi. (2008).

Metodologi Penelitian

Kebudayaan. Yogyakarta:

Gadjah Mada Press

Haryono. (2008). Hygiene

Lingkungan Kerja. Yogyakarta:

Mitra.

Hoed, Benny, H. (2007). Semiotik dan

Dinamika Sosial Budaya. Depok:

Fakultas Ilmu Budaya UI
Hoed, Benny H. (2014). Semiotik \&

Dinamika Sosial Budaya. Jakarta:

Komunitas Bambu

Holmes, Janet. (2001). An Introduction to Sociolinguistics. New

York: Longman

Indra, Made, I. Jendra. (2010).

Sociolinguistics: The Study of

Societies Language. Yogyakarta:

Graha Ilmu

Pradopo, Rachmat Djoko. (1995).

Beberapa Teori Sastra, Metode, dan.

Penggunaannya. Yogyakarta :

Pustaka Pelajar

Rokhmansyah, Alfian. (2014). Studi dan Pengkajian Sastra. Yogyakarta :

Graha Ilmu

Sibarani, $\quad$ Robert. 2004.

Antropolinguistik: Antropologi

linguistik, Linguistik Antropologi.

Medan: Penerbit Poda

Soedarsono, R.M. (2002). Seni

Pertunjukan Indonesia di Era

Globalisasi. Yogyakarta: Gadjah

Mada Press

Sulistyowati, Endang, dan Tarman

Tarsya Effendy. (2017). Kajian Prosa

Fiksi. Banjarbaru: Scripta Cendekia

Tinarbuko, Sumbo. (2008). Semiotika

Komunikasi Visual. Yogyakarta: Jalasutra.

Trask, R.L. (1996). Historical Linguistics.

London: Edward Arnold

Wibowo, Seto. (2011). Semiotika

Komunikasi. Jakarta: Mitra Wacana Media 